\title{
PROTOTIPE DATA WAREHOUSE PERIKANAN TANGKAP DAN BUDIDAYA
}

\author{
Rully Agus Hendrawan \\ Jurusan Sistem Informasi, Fakultas Teknologi Informasi, Institut Teknologi Sepuluh Nopember \\ Kampus Keputih, Sukolilo, Surabaya 60111 \\ Telp: (031) 5999944, Fax: (031) 5964965 \\ E-mail: eraha@is.its.ac.id
}

\begin{abstract}
In fisheries sector, decisions must be made to support the improvement of fishery resources management. Wise decision must be taken based on facts and data. Therefore, government provides fishery data and information center. Currently, the data are provided as electronic documents and displayed as table. These tables are made for specific perspectives. Thus, it made difficult for analysts to see the data in other perspectives. Online analytical processing (OLAP) have the characteristics especially made for decision-making. OLAP requires data warehouse $(D W)$. This paper presents a prototype of data warehouse systems that will collect, store, process and present data of capture and aquaculture fishery. The data involved are potency, infrastructure, facilities and production. This paper will explain why fishery needs data warehouse, and how to build it. The most suitable methodology for this case study is supply-driven. Furthermore, it will explain requirement analysis, data analysis, architectural design, and development process. Data warehouse is successfully implemented and used for reporting and OLAP.
\end{abstract}

Di bidang perikanan, keputusan diambil untuk menunjang peningkatan pelaksanaan pengelolaan sumber daya ikan. Keputusan yang bijaksana harus didukung dengan data dan fakta. Oleh karena itu, pemerintah mengadakan pusat data dan informasi perikanan berdasarkan Undang-undang Republik Indonesia Nomor 31 Tahun 2004 tentang Perikanan, khususnya pada Bab VI, pasal 46 dan 47. Saat ini, data tersebut tersimpan sebagai dokumen elektronik dan disajikan dalam bentuk tabel berdasarkan sudut pandang tertentu yang telah ditetapkan sebelumnya. Dengan kondisi seperti ini, akan sangat sulit apabila ingin menyajikan data dalam sudut pandang lain. Proses online analytical processing $(O L A P)$ memiliki karakteristik khusus yang memang dibuat dengan tujuan untuk mendukung pengambilan keputusan. Untuk dapat melakukan OLAP, dibutuhkan data warehouse (DW). Paper ini menyajikan protipe data warehouse untuk mengumpulkan, menyimpan, mengolah dan menyajikan data perikanan tangkap dan budidaya. Data tersebut antara lain potensi, sarana/prasarana, dan produksi. Dalam paper ini akan dijelaskan alasan mengapa bidang perikanan membutuhkan data warehouse, dan bagaimana membangunnya. Berdasarkan kenyataan di lapangan, metodologi pengembangan data warehouse yang digunakan adalah supply-driven. Dijelaskan juga analisis kebutuhan, analisis data, rancangan arsitektur, dan proses yang terlibat dalam pengembangan prototipe. Data warehouse terbukti berhasil diimplementasikan dan dapat dimanfaatkan untuk penyajian laporan dan OLAP.

Kata kunci: data warehouse, business intelligence, fishery.

\section{PENDAHULUAN}

Data dan informasi memegang peranan penting dalam pengambilan keputusan oleh pemerintah, akademisi maupun pihak swasta. Pada bidang perikanan, keputusan diambil untuk menunjang peningkatan pelaksanaan pengelolaan sumber daya ikan serta pengembangan sistem bisnisnya. Oleh karena itu, pemerintah mengadakan pusat data dan informasi perikanan berdasarkan Undang-undang Republik Indonesia Nomor 31 Tahun 2004 tentang Perikanan, khususnya pada Bab VI, pasal 46 dan 47.
Data tentang perikanan telah dikumpulkan, dikelola serta tersaji dengan baik di Aplikasi Sistem Informasi Diseminasi Data Statistik Kelautan dan Perikanan, Kementrian Kelautan dan Perikanan (Pusat Data, 2014). Data tersimpan sebagai dokumen elektronik dan disajikan dalam bentuk tabel berdasarkan sudut pandang tertentu yang telah ditetapkan sebelumnya. Berdasarkan direktorat yang ada, data perikanan dibagi menjadi tiga yaitu: Direktorat Jenderal Perikanan Tangkap (Ditjen PT), Direktorat Jenderal Perikanan Budidaya (Ditjen PB), dan 
Direktorat Jenderal Pengolahan dan Pemasaran Hasil Perikanan (Ditjen P2HP). Dengan kondisi seperti ini, akan sangat sulit apabila ingin menyajikan data dalam sudut pandang lain. Saat ini, proses tersebut harus dilakukan secara manual sehingga membutuhkan sumber daya manusia yang banyak dan waktu yang lama. Proses online analytical processing (OLAP) memiliki karakteristik khusus yang memang dibuat dengan tujuan untuk mendukung pengambilan keputusan (Inmon, 2002; Vassiliadis, 2000). OLAP membutuhkan data warehouse (DW) yaitu basis data yang bersifat subject-oriented, integrated, time-variant, dan nonvolatile.

Beberapa laporan penelitian di berbagai bidang telah menunjukkan kesuksesan penerapan data warehouse. Contohnya di bidang rekayasa konstruksi (Chau, 2003), pariwisata (Mirela, 2009) dan pusat medis (Jonathan, 2001). Di bidang perikanan, distribusi ikan merupakan informasi yang sangat penting (Ministry of Environment, 2014). Riset pemanfaatan data warehouse pada bidang ini meliputi pengumpulan dan pengolahan data (Jansen, 2008), serta beberapa pelajaran yang penting untuk dicermati dalam mengembangkannya (Butler, 2006).

Paper ini menyajikan protipe data warehouse untuk mengumpulkan, menyimpan, mengolah dan menyajikan data perikanan. Data tersebut antara lain potensi, sarana/prasarana, dan produksi. Sebagai studi kasus, digunakan data dari Dinas Perikanan dan Kelautan Propinsi Jawa Timur.

Paper ini disajikan secara berurutan sebagai berikut. Pada bagian 2 dijelaskan tentang alasan mengapa bidang perikanan membutuhkan data warehouse. Bagian 3 berisikan analisis kebutuhan, analisis data dan arsitektur yang dirancang khusus untuk kebutuhan bidang perikanan. Secara detil proses yang terlibat dalam pengembangan prototipe, serta penyajian laporan dan OLAP akan dijelaskan pada bagian 4. Pada bagian 5 dijelaskan tentang verifikasi dan validasi data warehouse ini. Kesimpulan dan saran pengembangan mendatang akan disajikan pada bagian 6 .

Untuk mengoptimalkan pembangunan di bidang Perikanan dan Kelautan, diperlukan data perikanan yang akurat dan terkini untuk diolah menjadi suatu informasi yang bermanfaat untuk para pejabat pengambil keputusan. Hasil pengamatan menunjukkan bahwa pengumpulan dan pengolahan data membutuhkan waktu yang lama sebelum analisis dapat dilakukan. Pengambil keputusan membutuhkan lebih banyak informasi, tetapi analis hanya dapat memberikan informasi yang sedikit dengan biaya yang tinggi pada rentang waktu yang diinginkan (Dyche, 2000).

Pemrosesan data perikanan dimulai dari proses pencatatan, pengumpulan, dan pengolahan data statistik yang meliputi data produksi, ekspor, pengolahan dan pemasaran, serta data pendukung lainnya. Wilayah perairan yang luas dan banyaknya data yang harus dikumpulkan mengakibatkan lamanya pemrosesan data menjadi informasi. Pemrosesan data perikanan saat ini, dilakukan secara konvensional. Format data perikanan yang beragam di tiap daerah, sangat memungkinkan terjadinya kesalahan dalam proses kompilasi. Pengiriman data yang terlambat menunjukkan ketidak-akuratan data antara laporan yang diterima dengan kondisi sebenarnya. Sehingga kualitas informasi menjadi kurang baik.

Data warehouse dapat memenuhi kebutuhan informasi dan mengatasi volume data yang semakin meningkat. Data warehouse bukanlah produk, melainkan sebuah lingkungan. Data warehouse adalah konstruksi arsitektural sistem informasi yang membantu penyediaan data terkini dalam kondisi yang akurat dan mudah diolah menjadi informasi sehingga pengambilan keputusan pun dilakukan secara tepat dan optimal. Sehingga, pengambil keputusan di bidang perikanan dapat mendapatkan yang dibutuhkan untuk membuat kebijakan dan mengambil langkah dalam membangun minapolitan. Contohnya, untuk meningkatkan produktivitas penangkapan dan budidaya ikan di daerah tertentu. Contoh lain menganalisis potensi perikanan daerah sehingga dapat meningkatkan ekonomi warga melalui budidaya perikanan laut, air payau, kolam, karamba, sawah tambak, dan media air lainnya.

\section{METODOLOGI}

Pengembangan data warehouse harus memperhatikan siklus hidupnya (Ralph, 2008). Metodologi pengembangan datawarehouse sangat beragam (List, dkk., 2002; Lawrence dkk., 2011). Pada umumnya metodologi ini terbagi menjadi beberapa fase:

1. Analisis kebutuhan: mengidentifikasi informasi mana yang terkait dengan proses pengambilan keputusan dengan mempertimbangkan kebutuhan pengguna atau melihat kenyataan atas ketersediaan data di sumber operasional.

2. Desain konseptual: bertujuan menurunkan skema konseptual untuk data mart

3. Desain logical: mengambil skema konseptual dan menurunkannya menjadi siap implementasi. Sistem data warehouse saat 
ini pada umumnya menggunakan relational logical model (ROLAP)

4. Desain proses ETL: memetakan transformasi data yang dibutuhkan sebelum dimasukkan ke dalam skema logical dan memastikan data tersedia pada sumber operasional

5. Desain fisikal: penyesuaian dengan teknologi yang dipilih supaya dapat memaksimalkan fitur pada saat implementasi.

Analisis kebutuhan dan desain konseptual memegang peranan yang sangat penting. $\mathrm{Ku}-$ rangnya pemahaman terhadap kebutuhan pengguna dan ketersediaan dari sumber data operasional menjadikan sulit dalam mengembangkan skema multidimensional yang tepat. Pada satu sisi skema ini harus memenuhi kebutuhan pengguna dan di sisi lain dipenuhi dari sumber data operasional.

Kebutuhan yang akan dijelaskan pada paper ini berfokus pada kebutuhan fungsional. Kebutuhan non-fungsional meliputi kemudahan penggunaan, keamanan, dan performa tidak dijelaskan lebih lanjut karena berkaitan dengan teknologi data warehouse yang dipilih.

\subsection{Analisis Sumber Data}

Analisis kebutuhan dilakukan dengan pendekatan supply-driven (atau biasa juga disebut data-driven). Pendekatan ini merupakan teknik bottom-up yang dimulai dari analisis sumber data operasional untuk mengidentifikasi semua data yang ada (Golfarelli, 2008; Jensen, dkk., 2004). Pengguna dilibatkan sebatas pada pemilihan bagian manakah dari data yang tersedia yang berhubungan dengan proses pengambilan keputusan. Pendekatan supply-driven cocok dipakai dalam kasus ini karena: pengetahuan yang mendetail tentang sumber data telah tersedia dan mudah didapat; skema sumber telah memiliki derajat normalisasi yang cukup baik; skema sumber data tidak sangat kompleks.

Sumber data didapatkan dari administrasi masing-masing unit eselon I lingkup KKP serta instansi terkait lainnya, yang tertuang dalam Buku Statistik Kelautan dan Perikanan tahun 20092011. Dari hasil analisis data tersebut dirancang kebutuhan fungsional, arsitektur serta model konseptual/logikal data warehouse.

\subsection{Kebutuhan Fungsional}

Kebutuhan fungsional dari sistem ini secara garis besar adalah sebagai berikut:

1. Pengumpulan beragam data dan informasi perikanan. Sistem harus dapat membantu mengumpulkan data yang dimiliki oleh KKP yang tersebar di berbagai lokasi.
Struktur data harus seragam. Terdapat fasilitas untuk membantu verifikasi dan validasi data.

2. Pengelolaan dan agregasi data perikanan menjadi informasi. Dari sekitar 137 macam bentuk laporan, dipilih 76 laporan yang harus terpenuhi. Laporan ini dipilih berdasarkan prioritas kebutuhan pengguna dan dikelompokkan dalam 9 kategori.

3. Pengolahan dan analisis data multidimensi (OLAP). Data dapat diolah ke sudut pandang yang berbeda dengan mudah. Pengguna dapat melakukan query dan perubahan sudut pandang dalam tatap muka grafis. Hal ini bisa dilakukan dengan menggunakan OLAP. Laporan tidak hanya berbentuk tabel, tetapi juga ditampilkan sebagai grafik.

\subsection{Arsitektur}

Dari kebutuhan fungsional tersebut dihasilkan rancangan arsitektur sistem seperti pada gambar 1. Arsitektur ini terdiri atas tiga fase. Fase yang pertama adalah akusisi data untuk mengumpulkan data yang dibutuhkan. Dalam fase ini, sebagian besar data didapatkan dari surveyor / admin lapangan. Sehingga dibutuhkan sistem yang memudahkan surveyor/admin dalam memasukkan dan mengelola data yang disimpan secara terpusat di dalam server tolok ukur. Fase ini modifikasi dari arsitektur umum data warehouse yang pada umumnya adalah melakukan ETL (Ekstraksi, Transformasi, dan Loading). ETL tidak dapat dilakukan mengingat sistem online transactional procession (OLTP) masih belum ada.

Fase kedua adalah data warehouse (gudang data). Data warehouse didesain dengan mengidentifikasi tolok ukur dan dimensi dengan metode supply-driven. Dalam fase ini juga dibangun kubik data multidimensional yang subjektif. Desain agregasi perlu diperhatikan di fase ini supaya proses OLAP berjalan lebih efisien. Fase yang terakhir adalah membangun aplikasi yang secara langsung dipakai oleh pengguna. Aplikasi ini akan memiliki fasilitas untuk menghasilkan laporan secara fleksibel dan dinamis, juga kemampuan menyajikan grafik, melakukan operasi OLAP seperti slice, dice, roll-up dan drill down.

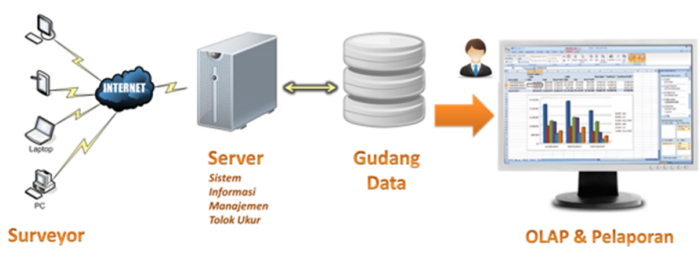

Gambar 1. Arsitektur Sistem 
Dengan adanya aplikasi ini pengguna dapat menghasilkan beraneka sudut pandang dengan memanfaatkan kubik data yang sama.

\section{HASIL dan PEMBAHASAN}

Tahapan pembuatan data warehouse akan dijelaskan sesuai dengan tiga fase yang ada pada arsitektur.

\subsection{Aplikasi Manajemen Tolok Ukur}

Pengumpulan data dilakukan secara manual. Data yang diperoleh dientrikan ulang ke dalam sistem menggunakan aplikasi desktop, yang dapat dilihat pada gambar 2. Aplikasi ini menampung data di komputer lokal, kemudian secara berkala dapat dikirimkan ke server. Server mengakumulasi data dari masing-masing sumber. Fasilitas untuk mengelola dan menyun-ting data juga disediakan untuk menjamin kualitas dan integritas data. Selain kebutuhan fungsional, dipertimbangkan pula aspek non-fungsional. Entri data dibuat semudah mungkin dengan meminimalisasi penggunaan mouse. Aplikasi dapat dioperasikan dengan mudah dan cepat memakai keyboard. Shortcut dan navigasi juga dibuat semudah mungkin untuk mempercepat proses pengumpulan data.

\subsection{Skema Datawarehouse}

Data warehouse dirancang dengan menggunakan skema bintang (star schema) (Jensen, 2004). Dari proses perancangan, dihasilkan empat tabel fakta dan delapan tabel dimensi. Keempat tabel fakta yang dimaksud adalah penangkapan, armada, produksi budidaya, dan pembenihan budidaya. Sedangkan tabel dimensinya adalah armada, asal ikan, lokasi, waktu, ikan, alat tangkap, pupuk, dan jenis perairan. Skema lebih detil dapat dilihat pada gambar 3 . Tipe data dari masing-masing kolom disesuaikan dengan contoh data yang ada. Penyesuaian kadang perlu dilakukan karena contoh data kurang mewakili seluruh data.

\subsection{Aplikasi OLAP dan Laporan}

Aplikasi analisis yang digunakan langsung oleh pengguna dibangun berbasis desktop. Basis desktop dipilih karena kebutuhan non-fungsional, dimana aplikasi harus mudah dipakai dan dapat berinteraksi dengan sistem operasi ataupun software perkantoran. Aplikasi ini memanfaatkan pustaka dari pihak ketiga (third party) untuk menangani proses dan operasi OLAP, dan penyajian grafik.

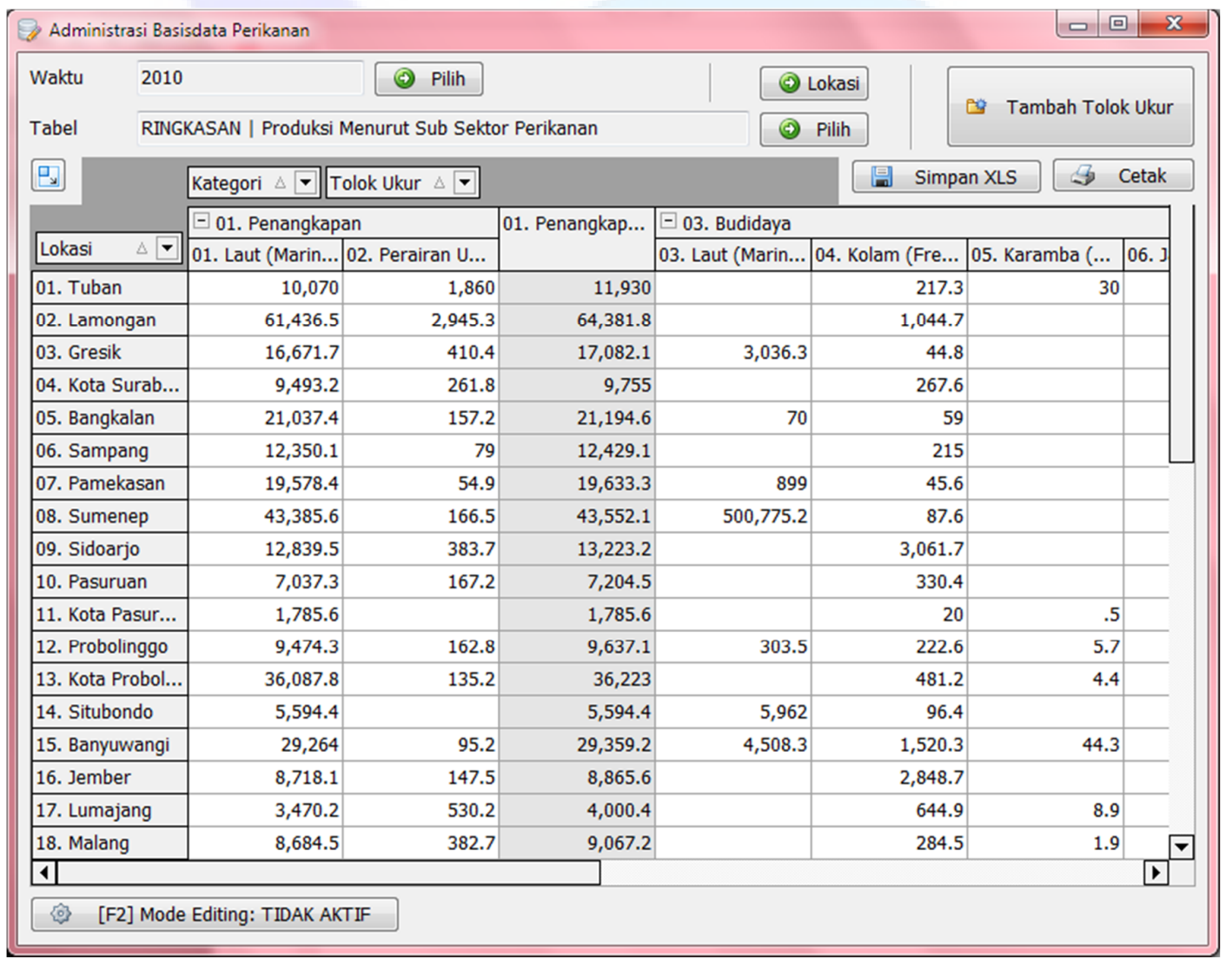

Gambar 2. Manajemen Tolok Ukur 


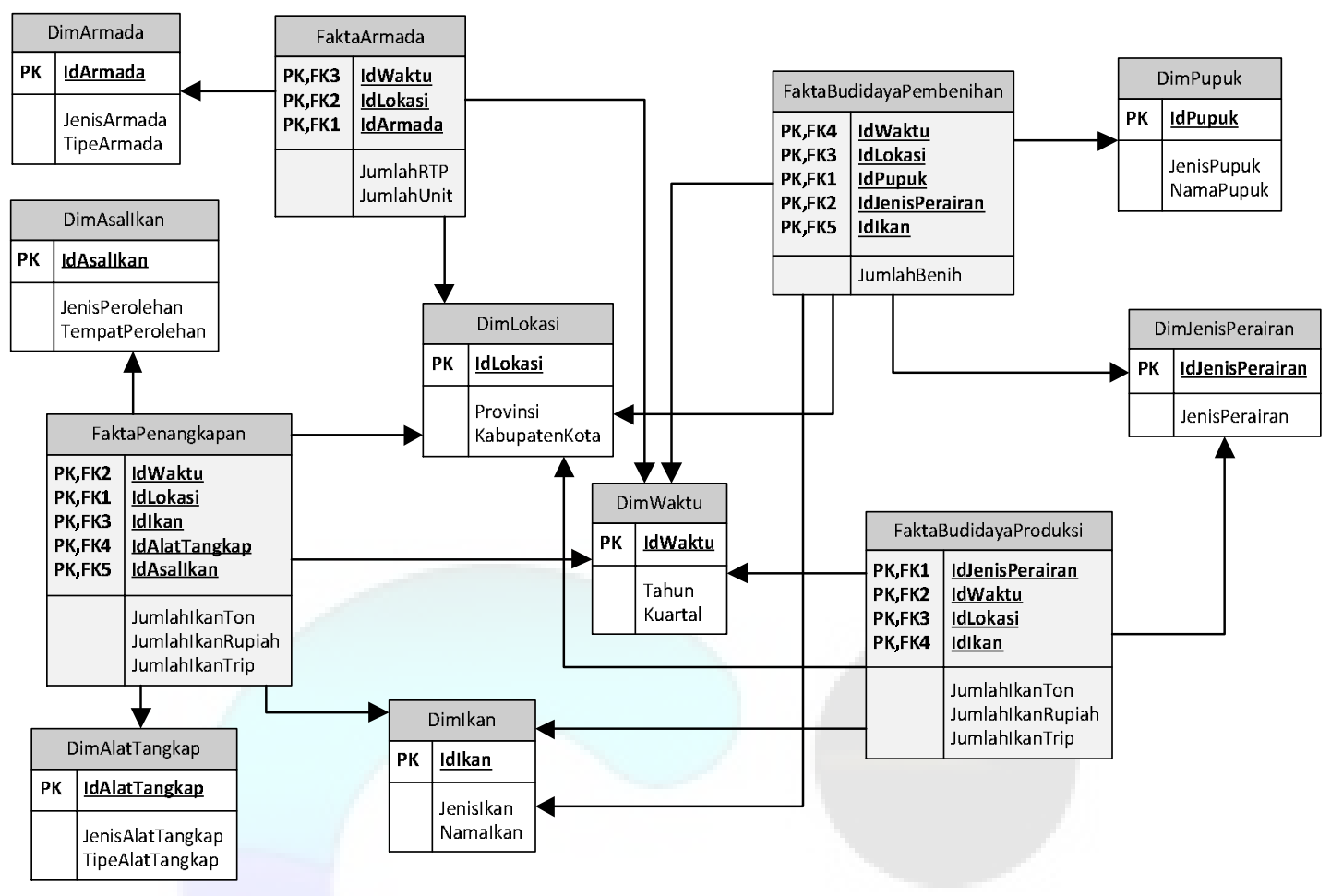

Gambar 3. Skema Datawarehouse

Pengguna dapat melakukan operasi OLAP yaitu slice, dice, roll up dan drill down dalam antarmuka grafis. Pengguna dapat memilih dimensi mana yang ingin dipakai dan nilai tolok ukur apa yang ingin ditampilkan. Hasil operasi OLAP akan ditampilkan dalam bentuk tabel seperti pada gambar 4. Hasil dari operasi OLAP juga dapat di-ekspor untuk diolah lebih lanjut menggunakan software perkantoran. Selain itu untuk mempermudah memahami informasi, hasil operasi OLAP juga dapat disajikan dalam bentuk grafik. Grafik yang dibuat untuk melihat tren dapat dilihat pada gambar 5 .

\subsection{Verifikasi dan Validasi}

Verifikasi dilakukan untuk memastikan sistem bekerja sesuai rancangan. Sedangkan validasi memastikan sistem telah dibangun sesuai kebutuhan.

\section{Verifikasi}

Verifikasi dilakukan dengan metode blackbox, yaitu dengan menyesuaikan hasil dengan informasi yang telah kita buat secara manual. Data dilakukan secara bertingkat untuk memastikan sistem bekerja sesuai rancangan. Terdapat dua tingkatan verifikasi data, yaitu:
1. Tingkatan paling detil (grain level) Setiap kali data masuk dan tersimpan, maka dilakukan proses pengecekan ulang (proof read) untuk memastikan kebenaran data. Apabila data sudah diyakini benar, maka baru kemudian data dikirimkan ke server data warehouse.

\section{Agregasi Dimensi}

Data hasil perhitungan agregasi ditampilkan sesuai dengan laporan yang telah dikerjakan secara manual. Misalnya, laporan jumlah penangkapan per kabupaten/kota. Nilai yang muncul dari hasil operasi OLAP dicocokkan satu per satu dengan laporan yang kita miliki.

\section{$\underline{\text { Validasi }}$}

Validasi dilakukan untuk memastikan data warehouse yang dibangun telah memenuhi semua kebutuhan fungsional. Validasi dilakukan dengan membuat query OLAP untuk semua laporan yang dibutuhkan dan melihat apakah sama dengan laporan aslinya yang dibuat secara manual. Sebanyak 76 laporan digunakan untuk validasi data warehouse tersebut. Hasil validasi menunjukkan bahwa datawarehouse dapat digunakan untuk menghasilkan seluruh laporan dengan mengubah perspektif melalui pemilihan dimensi, hirarki, serta operasi OLAP yang tepat. 
Hendrawan, Prototipe Data Warehouse Perikanan Tangkap dan Budidaya

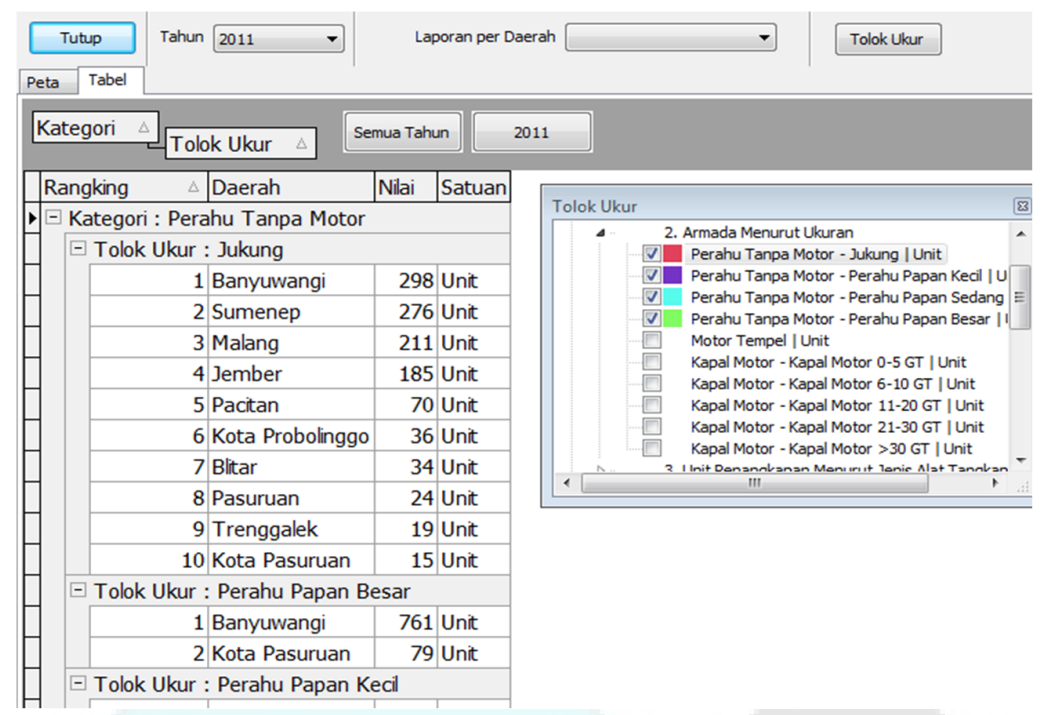

Gambar 4. Laporan OLAP dalam Bentuk Tabel

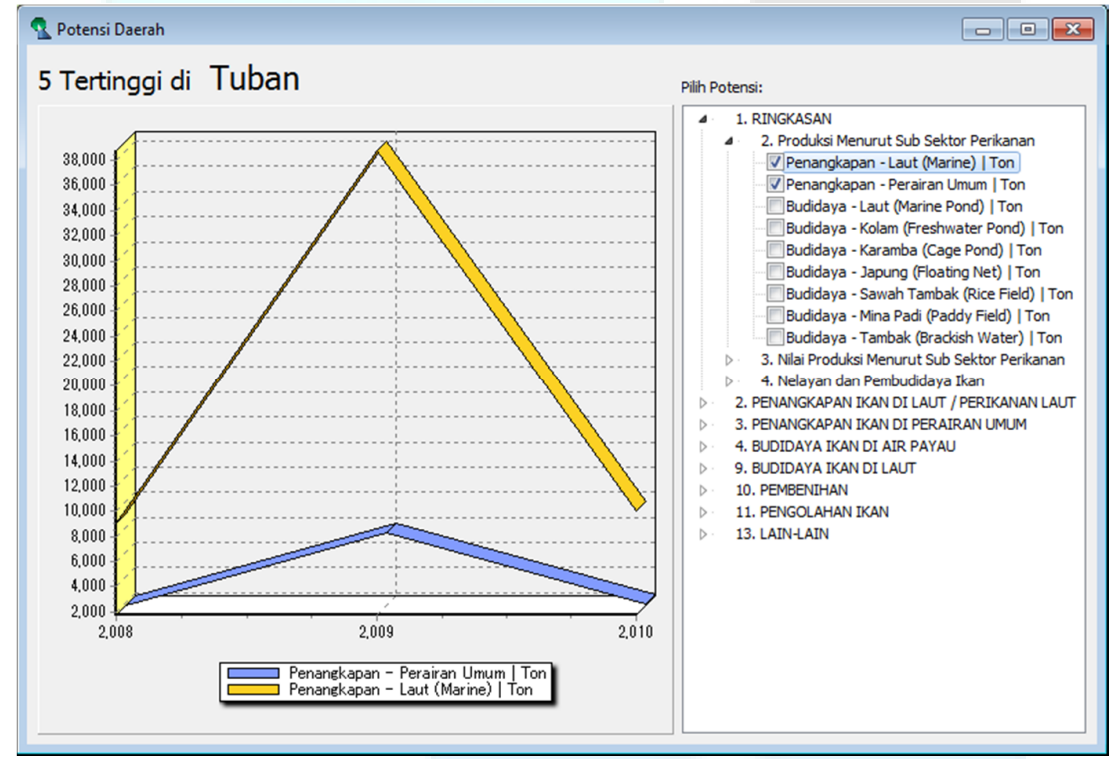

Gambar 5. Laporan OLAP dalam Bentuk Grafik

Table 1 Validasi Data Warehouse dengan Kebutuhan Fungsional

\begin{tabular}{lll}
\hline Jenis Laporan & LK $^{*}$ & LD $^{* * *}$ \\
\hline $\begin{array}{l}\text { Penangkapan ikan di laut / } \\
\text { perikanan laut }\end{array}$ & 13 & 13 \\
$\begin{array}{l}\text { Penangkapan ikan di perairan } \\
\text { umum }\end{array}$ & 12 & 12 \\
$\begin{array}{l}\text { Budidaya ikan di air payau } \\
\text { Budidaya ikan di kolam }\end{array}$ & 10 & 10 \\
Budidaya ikan di karamba & 9 & 9 \\
$\begin{array}{l}\text { Budidaya ikan di sawah tambak } \\
\text { dan mina padi }\end{array}$ & 8 & 8 \\
$\begin{array}{l}\text { Budidaya ikan di jaring apung } \\
\text { Budidaya ikan di laut }\end{array}$ & 6 & 6 \\
Pembenihan & 5 & 5 \\
\hline
\end{tabular}

*) Jumlah Laporan yang Ada

${ }^{* *)}$ Jumlah Laporan dari Data warehouse

\section{SIMPULAN dan SARAN}

Dalam paper ini telah dijelaskan bagaimana pengembangan prototipe data warehouse pada bidang perikanan yang telah validasi kegunaannya untuk menghasilkan laporan dan OLAP. Dalam studi kasus pengguna dapat berinteraksi dengan sistem dan membuat beraneka ragam tampilan sesuai dengan sudut pandang yang dikehendakinya. Data warehouse juga telah divalidasi untuk memenuhi kebutuhan dasar laporan yang ada saat ini.

Pengembangan utama di masa mendatang akan meliputi dua hal. Yang pertama adalah membuat mekanisme pengumpulan data yang lebih efisien. Misalnya dengan memanfaatkan teknologi bergerak, atau dengan integrasi dengan sumber data yang sudah ada secara online. Dan 
yang kedua adalah pendayagunaan lebih lanjut data warehouse. Salah satunya adalah visualisasi data pada peta sehingga lebih mudah dalam melakukan analisis spasial.

Kebutuhan non-fungsional seperti performa juga akan menjadi bahan pengembangan lebih lanjut. Volume data yang besar sangat berpengaruh pada kecepatan akusisi data pada tahap ETL dan dan kecepatan penyajian informasi pada OLAP. Dalam kasus ini, performa belum menjadi masalah karena butiran data yang cukup besar dan lingkup yang relatif kecil (Jawa Timur). Sejauh ini dapat diatasi dengan meningkatkan daya komputasi (prosesor yang lebih cepat dan memori yang lebih besar). Supaya dapat diterapkan untuk lingkup yang lebih luas, perlu diadakan uji performa dan penelitian tentang faktor-faktor apa saja yang mempengaruhi efisiensi rancangan pada data besar.

\section{DAFTAR RUJUKAN}

Butler, C., 2006. Ten Lessons Learned: Data Warehouse Development Project, California Department of Fish and Game. The Journal of Defense Software Engineering, 19 (10).

Chau, K., Cao, Y., Anson, M., Zhang, J., 2003. Application of data warehouse and Decision Support System in construction management. Automation in Construction. Elsevier, 2003.

Dyche, J.. 2000. e-Data Turning Data into Information with Data Warehousing. Reading : Addison-Wesley.

Golfarelli, M., 2008. The DFM: A Conceptual Model for Data Warehouse. Encyclopedia of Data Warehousing and Mining(Second Edition), John Wang (Ed.), IGI Global.

Inmon, W. H., 2002. Building the Data Warehouse. Third edition. USA: John Wiley \& Sons.

Jensen, M., Holmgren, T., \& Pedersen, T. 2004. Discovering Multidimensional Structure in Relational Data. Proceedings of International Conference on Data Warehousing and Knowledge Discovery, 3181, pp. 138148.

Jansen, T., Degel, H., Haakansson, K., Egekvist, J., Dalskov, J.. 2008. FishFrame 5.0: A web based datawarehouse application for management, access and integration of fisheries and stock assessment data. ICES Annual Science Conference. Halifax, Jan 2008. ICES: Canada.
Jonathan, S., 2001. Case Study: A Data Warehouse for an Academic Medical Center. Journal of Health Care Information Management, 15 (2), pp.165-175

Kementrian Kelautan dan Perikanan, 2011. Buku Statistik Kelautan dan Perikanan 2011. Jakarta: Kementrian Kelautan dan Perikanan.

Kementrian Kelautan dan Perikanan, 2010. Buku Statistik Kelautan dan Perikanan 2010. Jakarta: Kementrian Kelautan dan Perikanan.

Kementrian Kelautan dan Perikanan, 2009. Buku Statistik Kelautan dan Perikanan 2009. Jakarta: Kementrian Kelautan dan Perikanan.

List, B., Bruckner, R., Machaczek, K., Schiefer, J., 2002. A Comparison of Data Warehouse Development Methodologies - Case Study of the Process Warehouse. 13th International Conference on Database and Expert Systems Applications. Vienna, 2002, ISIS: Vienna.

Lawrence, C., Jim, S., 2011. Agile Data Warehouse Design: Collaborative Dimensional Modeling, from Whiteboard to Star Schema. DecisionOne Consulting.

Ministry of Environment, British Columbia, 2014. Fisheries Inventory. [Online] Available at: http://www.env.gov.bc.ca/fish/methods/index.html [Accessed 29 Des 2013]

Mirela, D., 2009. Some Aspects of Data Warehousing in Tourism Industry. The Annals of the "Stefan cel Mare" University of Suceava. Fascicle of The Faculty of Economics and Public Administration. Suceava, 2009, University of Suceava: Suceava.

Pusat Data, Statistik dan Informasi Kementrian Kelautan dan Perikanan, 2014. SIDATIK. [Online] Available at: http://statistik.kkp.go.id [Accessed 29 Des 2013]

Ralph, K., Margy, R., Warren, T., Joy, M., Bob, B., 2008. The Data Warehouse Lifecycle Toolkit. John Wiley \& Sons.

Vassiliadis, P.. 2000. Data Warehouse Modeling and Quality Issues. Ph. D. Greece: Department of Electrical and Computer Engineering, National Technical University of Athens. 